\title{
Hazard Assessment of Alternatives to Dicofol
}

\author{
Ana I. Sánchez ${ }^{1 *}$, M. Dolores Hernando ${ }^{1}$, Juan J. Vaqueroº ${ }^{2}$ Eloy García ${ }^{3,4}$, José M. Navas ${ }^{5}$ \\ ${ }^{1}$ Parque Científico Tecnológico, University of Alcala, Alcalá de Henares, Madrid, Spain; ${ }^{2}$ Department of Organic Chemistry, Faculty \\ of Pharmacy, University of Alcala, Alcalá de Henares, Madrid, Spain; ${ }^{3}$ Department of Analytical Chemistry and Engineering Chem- \\ istry, Faculty of Chemistry, University of Alcala, Alcalá de Henares, Madrid, Spain; ${ }^{4}$ IMDEA Water Foundation, Alcalá de Henares, \\ Madrid, Spain; ${ }^{5}$ Department of Environment, Spanish National Institute for Agricultural and Food Research and Technology (INIA), \\ Madrid, Spain \\ Email: anasanchez@cnrcop.es
}

Received April 21 ${ }^{\text {st }}, 2010$; revised May $12^{\text {th }}, 2010$; accepted May $22^{\text {nd }}, 2010$.

\begin{abstract}
Dicofol was listed by International POPs Elimination Network (IPEN) as requiring immediate and urgent consideration and thus was considered as a new candidate by Persistent Organic Pollutant Review Committee (POPRC) as a possible persistent organic pollutant (POP). Dicofol is structurally similar to DDT. It is persistent in food and water, highly toxic to aquatic life and causes egg-shell thinning in some bird species. High concern, due to the lack of dicofol measurements in the Arctic, proving long range transport and bioaccumulation in wild life species, supports further impact assessment of this product. Under Stockholm Convention, substances identified as POPs are regulated with the objective to protect the environment and the human health. According to this objective, the search of environmental and healthy alternatives is helpful. This paper discusses the use of three groups of chemicals currently applied as alternatives to dicofol. An exhaustive review of the synthesis of dicofol, starting from DDT, and compared to possible substitutes is presented: 1) active principle with fluoralkenyl are proposed as an environmental and healthy alternative to dicofol, 2) inhibitor agents of mitochondrial electron transport as chlorfenapyr, hydramethylnon and pyridaben and 3) pesticides commonly applied in agricultural practices as oxythioquinox, fenbutatin-oxide and formetanate hydrochloride.
\end{abstract}

Keywords: Dicofol, POPs, Chemical Structure, Effects, Alternatives

\section{Introduction}

Dicofol (1,1'-bis( $p$-chlorophenyl)-2,2,2-trichloro-ethanol) is an organochlorine compound, miticide and acaricide. It is applied in a wide variety of crops, fruits, vegetables, ornamental and field crops. The use of this product is extended on more than 30 countries, and on more than 60 different crops (aprox. 0.4 to $3.0 \mathrm{Kg}$ a.i./ha) [1].

The worldwide consumption of dicofol is 2750 tons/ year as the following: 290 tons/year in Western Europe, 180 tons/year in Africa and Western Asia, 1820 tons/year in Asia, 170 tons/year in South America and 290 tons/ year in North America. In Spain the use is 100-150 tons/ year [2].

Dicofol production was temporarily banned by U.S. EPA in 1986. Afterwards it was reinstated as consequence of a new manufacturing process which produced technical-grade dicofol $(<0.1 \%$ DDTr, DDT and related substances). DDTr level in dicofol can't exceed $0.1 \%$ in Canada.
The use of dicofol is allowed in several countries of the EU (451/2000) [3]. Council Directive 79/117/EEC prohibits the use and marketing of products containing less than $78 \% p, p^{\prime}$-dicofol or more than $1 \mathrm{~g} / \mathrm{kg}(=0.1 \%)$ of DDTr.

Persistent, bioaccumulative and toxic substances (PBTs) and Persistent Organic Pollutants (POPs) are identified or addressed through various national, regional and global initiatives [4]. In the Stockholm Convention framework, the assessment of POPs is described as an evaluation of whether the chemical is likely, to lead to significant adverse human health and/or environmental effects, as a result of its long range environmental transport, so that global action is warranted.

Dicofol is currently under a review process for its designation as POP under the Stockholm Convention. Dicofol meets POP criteria but further assessment is needed regarding ecotoxicity of metabolites, monitoring in remote areas of dicofol and its metabolites [5]. 
Dicofol is degraded in water, sediments and soil. In water, $p, p$ '-dicofol meets the persistence criteria with a half life of two months at $\mathrm{pH}=5 ; o, p^{\prime}$-isomer has a half life of 47, 0.3 and $<0.1$ days at $\mathrm{pH} 5,7$ and 9 respectively; $p, p^{\prime}$-isomer has a half life of 85,4 and $<0.1$ days at $\mathrm{pH} 5,7$ and 9 respectively. In sediments, isomers $o, p$ 'and $p, p^{\prime}-(\mathrm{pH}$ of aqueous phase between 7.6 and 7.8) fail the persistence criteria, as the half life is lower than one day. The half life of dicofol metabolites in sediments is between 7 and 429 days. In soils, half life of the $o, p^{\prime}-$ and $p, p$ '-isomer is between 8 and 35 days, and between 21 and 60 days, respectively [5].

The mechanism of bioaccumulation of dicofol is similar to other POPs. Dicofol has a log Kow of 4.08-5.02 and a bioconcentration factor in fish of 8050-13000.

Due to its vapour pressure $(1 \mathrm{~Pa})$ and estimated half life in atmosphere (3.1 days), dicofol is expected to volatilise significantly and it is assumed to be transported in the atmosphere. Up to now, it is worthy of note that no monitoring data are available in remote areas. It has been hypothesized that dicofol may be globally distributed and should meet criterion for potential long-range atmospheric transport.

Dicofol is fairly toxic to mammals but isn't carcinogenic. It is reported to be repro-toxic in wildlife, and it may reduce eggshell quality as well. Dicofol is very toxic for aquatic organisms with lethal/effective concentration, $\mathrm{L}(\mathrm{E}) \mathrm{C}_{50}$ values of $15-120 \mu \mathrm{g} / 1$ obtained by acute toxicity tests and, no observed effect concentration, NOEC values of 4.4-125 $\mu \mathrm{g} / \mathrm{l}$ for chronic effects. Evidence of induction hepatic microsomal metabolism is available for rats [6]. Metabolites show similar toxic effects for aquatic organism based on range-finding studies and quantity structure-activity relationship (QSAR) model estimations. In Scheme 1, degradation (biotic and abiotic) pathways of dicofol and metabolites are shown [7].

This work shows a review of possible substitution alternatives to dicofol from the chemical perspective, analyzing the product synthesis, its chemical structure and its effects on the environment and human health. Target chemical groups in this article are: 1) active principles such as fluoralkenyl derivatives introduced as an environmental and healthy solution to dicofol, 2) second group based on the mode of action, mitochondrial electron transport inhibitors as chlorfenapyr, hydramethylnon and pyridaben; and 3) alternative pesticides commonly used in agricultural practices as oxythioquinox, fenbutatin-oxide and formetanate hydrochloride.

\section{Chemistry Facts}

\subsection{DDT and Dicofol Synthetic Processes}

DDT is produced as an intermediate in dicofol synthesis.

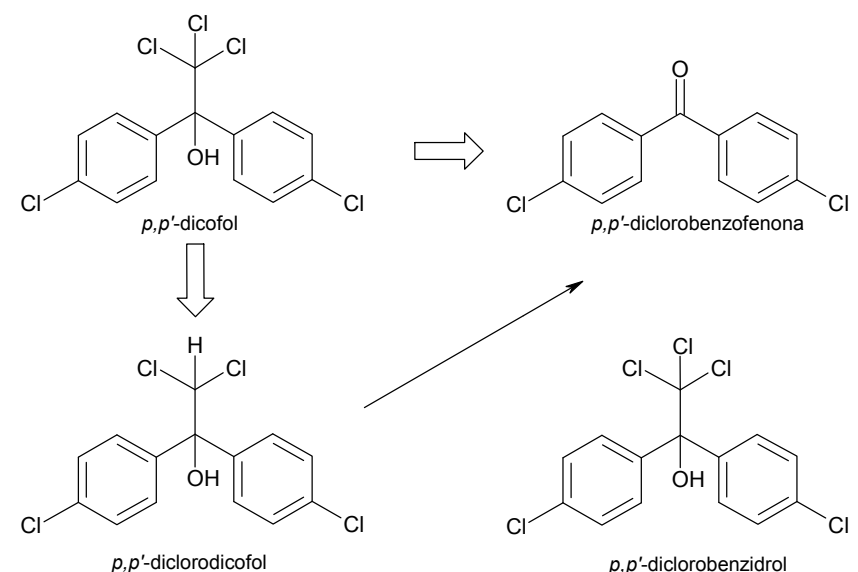

Scheme 1. Metabolite pathway in dicofol transformation. Reaction pathways shown are from Brown \& Casida (1987). Arrow thickness is added to roughly indicate relative rates of conversion.

The active ingredient dicofol is a mixture of approximately $80 \%$ of $p, p^{\prime}$-dicofol and $20 \%$ of $o, p$ '-dicofol [8]. It is produced by hydroxylation reaction of DDT, which is an emulsionable concentrate and can be commercialized as wettable tablets or water-soluble.

DDT was first synthesized in 1874 by Zeidler and its insecticidal properties were discovered by J.R. Geigy. The formation of technical DDT was optimized by Mosher, improving the original synthesis by Zeidler and the variation of Baeyer [9], Scheme 2 .

The reaction rate at low temperatures is slow, and at high temperatures results on the degradation of the product, although this can be avoided by using major acid concentration and lower temperature, or by using diluted acid and higher temperatures. A secondary reaction it is always raised, that supposes the chlorobenzene sulfonation. At last, the higher DDT yield is obtained at $90^{\circ} \mathrm{C}$, with a $98 \%$ sulphuric acid concentration, and a 1:4 chlorobenzene excess, stirring for $8 \mathrm{~h}$ at $5-10^{\circ} \mathrm{C}$, DDT yield is $97 \%$.

Technical DDT contains approximately $77 \%$ of $p, p$ 'DDT, $15 \%$ of $o, p^{\prime}$-DDT and $1.5 \%$ of an oily compound that is 2-trichloro-1-p-chloro-phenylethanol.

DDT synthesis was optimized using fluorhydric acid as condensing agent [10], Scheme 3.

Latterly, DDT analogues synthesis has been prepared to examine its insecticidal properties [11].

Dicofol is produced from chloral (trichloroacetic aldehyde), monochlorobenzene and oleum (fuming sulphuric acid: sulphur VI containing excess of sulphur trioxide),

\section{Scheme 4.}

Another synthetic process used to obtain technical dicofol was developed by Tang [12], it starts from DDT 


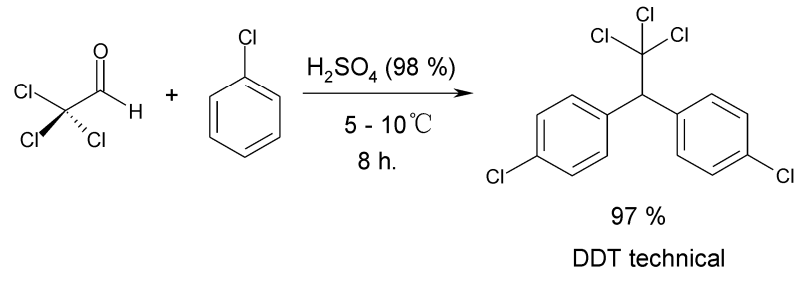

Scheme 2. Preparation of technical DDT.

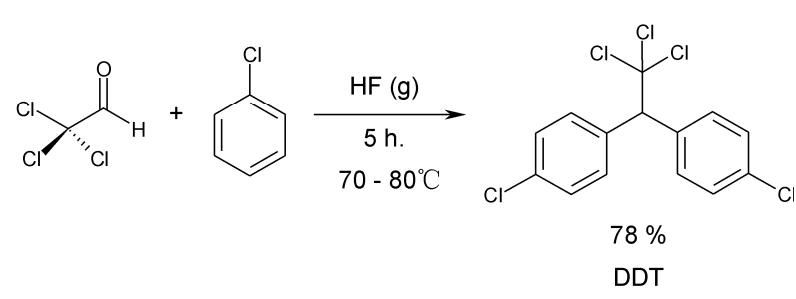

Scheme 3. Improved preparation of technical DDT.

and after chlorination and hydrolysis the desired product is obtained, Scheme 5. Impurities generated throughout the synthetic process are DDT and Cl-DDT.

\subsection{Alternative Products}

The pesticidal natural action of a compound is predominantly associated with its structure [13]. Also, the different moieties attached to parent compound, their spatial arrangements within the molecule, nature of substituents, polarity, symmetry and asymmetry of molecules, the solubility, sorption values, etc., have a direct or indirect bearing on the toxicity of the parent pesticidal compound. So, having an insight into the structure and toxicity relationship within each class of pesticides provides a better understanding of this correlation. The understanding of this relationship is vital in order to generate a molecule with a tailored fragment powered to act on the pests.

\subsubsection{Fluoralkenyl Derivatives}

Fluoroalkenyls [14], including all the geometric and stereoisomers, N-oxides, and salts thereof, can be an option to dicofol. These are compounds of Figure 1 wherein $\mathrm{X}$ is $\mathrm{H}, \mathrm{F}, \mathrm{C} 1-\mathrm{C} 4$ haloalkyl, $\mathrm{A}$ is $\mathrm{O}, \mathrm{S}$ or $\mathrm{NR}^{1}$; $\mathrm{B}$ is $\mathrm{C} 1-\mathrm{C} 4$ alkylene; $\mathrm{Y}$ is a 5- or 6-membered heteroaromatic ring or an aromatic 8-, 9- or 19-membered fused heterobicyclic ring system, each ring or ring system optionally substituted with 1 to 6 substituents independently selected from $\mathrm{R}^{2}$, or $\mathrm{Y}$ is $\mathrm{O}\left(\mathrm{CH}_{2} \mathrm{CH}_{2} \mathrm{O}\right) \mathrm{mR}^{3}$; and $\mathrm{R}^{1}, \mathrm{R}^{2}$ and $R^{3}, n$ and $m$ are as defined in the figure. These products have showed extremely effective for controlling invertebrate pest comprising contacting the invertebrate pest or its environment, thus an amount of a fluoroalkenyl compound is conjugated with an amount of at least one additional biologically active compound or agent.

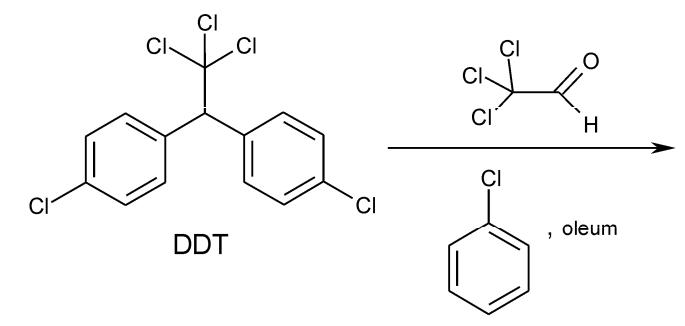

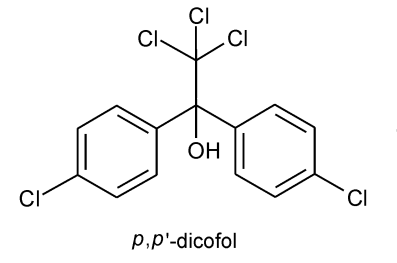

$(80 \%)$<smiles>O=C(O)c1ccccc1C(O)(c1ccc(Cl)cc1)C(Cl)(Cl)Cl</smiles>

$(20 \%)$

\section{Scheme 4. Synthesis of dicofol starting from DDT.}

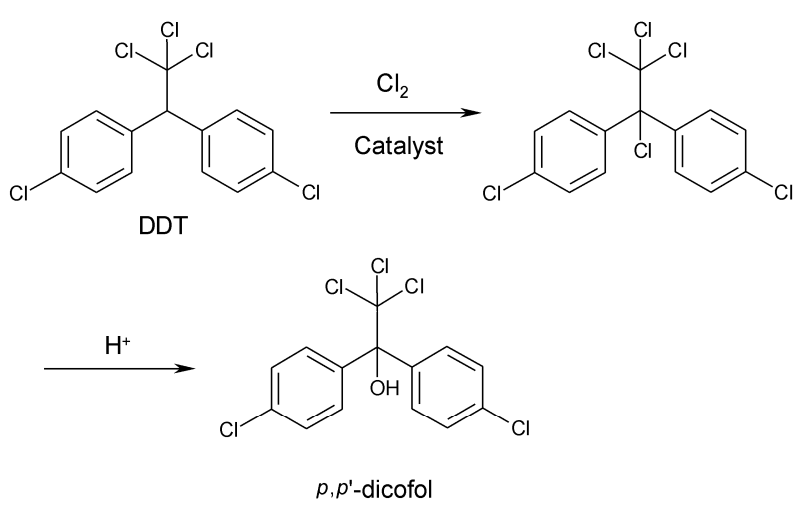

Scheme 5. Alternative synthesis of dicofol starting from DDT.<smiles>[Y]B[Hg]C(=O)[14CH2]CCCC([X])=C(F)F</smiles>

Figure 1. Fluoroalkenyl derivatives.

These additional biologically active compounds are showed on Table 1.

The mode of action of the pesticide in target organism is closely associated with the structure of the pesticidal compound. The structure of the parent molecule of structure is not only responsible for the activity but also the nature of substituents, or also the presence of an epoxide ring, double-triple bond, conjugation, aromaticity and stereochemistry determine the toxicity of the pesticidal compound. So, understanding of the structure of 
Table 1. Control agents for invertebrate pest based on its mode of action.

\begin{tabular}{|c|c|}
\hline Mode of Action & Control Active Principle \\
\hline $\begin{array}{l}\text { Sodium channel } \\
\text { modulators }\end{array}$ & $\begin{array}{l}\text { Bifenthrin, cypermethrin, cyhalothrin, } \\
\text { lambda-cyhalothrin, cyfluthrin, beta- } \\
\text { cyfluthrin, deltamethrin, dimefluthrin, } \\
\text { esfenvalerate, fenvalerate, indoxacarb, } \\
\text { metofluthrin, profluthrin, pyrethrin and } \\
\text { tralomethrin. }\end{array}$ \\
\hline $\begin{array}{l}\text { Acetyl cholinesterase } \\
\text { inhibitors }\end{array}$ & $\begin{array}{l}\text { Chlorpyrifos, methomyl, oxamyl, thio- } \\
\text { dicarb, formetanate hydrochloride and } \\
\text { triazamate. }\end{array}$ \\
\hline $\begin{array}{l}\text { Neocotinic receptor } \\
\text { modulator }\end{array}$ & $\begin{array}{l}\text { Acetamiprid, clothianidin, dinotefuran, } \\
\text { imidacloprid, nitenpyram, nithiazine, } \\
\text { thiacloprid and thiamethosam. }\end{array}$ \\
\hline $\begin{array}{l}\text { Insecticidal } \\
\text { macrocycles lactones } \\
\text { (Gamma-aminobutyric }\end{array}$ & $\begin{array}{l}\text { Spinetoram, spinosad, abamectin, aver- } \\
\text { mectin and emamectin. }\end{array}$ \\
\hline $\begin{array}{l}\text { acid)-regulated chloride } \\
\text { channel modulators } \\
\text { [GABA] }\end{array}$ & $\begin{array}{l}\text { Endosulfan, dicofol, ethiprole and } \\
\text { fipronil. }\end{array}$ \\
\hline $\begin{array}{l}\text { Chitin synthesis } \\
\text { inhibitor }\end{array}$ & $\begin{array}{l}\text { Buprofezin, cyrimazine, flufenosuron, } \\
\text { hexaflumuron, lufenuron, novaluron, } \\
\text { noviflumuron and triflumuron. }\end{array}$ \\
\hline $\begin{array}{l}\text { Juvenile hormone } \\
\text { mimics }\end{array}$ & $\begin{array}{l}\text { Diofenolan, fenoxycarb, methoprene } \\
\text { and pyriproxyfen. }\end{array}$ \\
\hline $\begin{array}{l}\text { Inhibitors of oxidative } \\
\text { phosphorylation, dis- } \\
\text { rupters of ATP forma- } \\
\text { tion (inhibitors of ATP } \\
\text { synthase) }\end{array}$ & Fenbutatin-oxide. \\
\hline $\begin{array}{l}\text { Octapamine receptor } \\
\text { modulators }\end{array}$ & Amitraz. \\
\hline $\begin{array}{l}\text { Ecdysone receptor } \\
\text { agonists }\end{array}$ & $\begin{array}{l}\text { Azadirachtin, methosyfenozide and te- } \\
\text { bufenozide. }\end{array}$ \\
\hline $\begin{array}{l}\text { Ryanodine receptor } \\
\text { ligands }\end{array}$ & $\begin{array}{l}\text { Ryanodine, anthranilic diamides such us } \\
\text { chloroantraniliprole and flubendiamide. }\end{array}$ \\
\hline Nereistoxin analogs & Cartap. \\
\hline $\begin{array}{l}\text { Mitochondrial electron } \\
\text { transport inhibitors }\end{array}$ & $\begin{array}{l}\text { Chlorfenapyr, hydramethylnon and pyri- } \\
\text { daben. }\end{array}$ \\
\hline $\begin{array}{l}\text { Lipid biosynthesis } \\
\text { inhibitors }\end{array}$ & Spirodiclofen and spiromesifen. \\
\hline $\begin{array}{l}\text { Disrupting protein } \\
\text { function }\end{array}$ & Oxythioquinox. \\
\hline $\begin{array}{l}\text { Cyclodiene } \\
\text { insecticides }\end{array}$ & $\begin{array}{l}\text { Dieldrin, cyflumetofen, fenothiocarb, } \\
\text { flonicamid, metaflumizone, pyrafluprole, } \\
\text { pyridalyl, pyripole, spirotetramat and } \\
\text { thiosultap-sodium. }\end{array}$ \\
\hline $\begin{array}{l}\text { Nucleopolyhedrovirus } \\
\text { mixture }\end{array}$ & $\begin{array}{l}\text { HzNPV and AfNPV. Bacillus thur- } \\
\text { ingiensis and encapsulated delta-endo- } \\
\text { toxins or Bacillus thuringiensis such us } \\
\text { Celicap, MPV and MPVII, as well as } \\
\text { naturally occurring and genetically mo- } \\
\text { dified viral insecticides including mem- } \\
\text { bers of the family Baculoviridae as well } \\
\text { as entomophagous fungi. }\end{array}$ \\
\hline
\end{tabular}

compounds and their correlation with toxicity to target organism is a very important parameter for developing better designed pesticidal compounds with tailored toxicidal properties on different pests.
These invertebrate pests can be arthropods (e.g. insects, mites, spiders, scorpions, centipedes, millipedes, pill bugs and symphylans, etc.), gastropods (e.g. snail, slugs, etc.) and nematodes (e.g. warms, etc.).

These compounds can generally be used as a formulation or a composition with a carrier suitable for agronomic or nonagronomic uses comprising at least one of a liquid diluent, a solid diluent or a surfactant. The formulation or composition ingredients are selected to be consistent with the physical properties of the active ingredient, mode of application and environmental factors such as soil type, moisture and temperature. Useful formulations include liquids such as solutions (including emulsifiable concentrates), suspensions, emulsions (including microemulsions and/or suspoemulsions) and the like which optionally can be thickened into gel; others include solids such as dusts, powders, granules, pellets, tablets, films (including seed coatings), and the like which can be water-dispersible ("wettable") or watersoluble. Encapsulation can control or delay release of the active ingredient. Sprayable formulations can be extended in suitable media and used at spray volumes from about one to several hundred liters per hectare.

\subsubsection{Inhibition Agents Acting as Mitochondrial Electron Transport}

Pardini et al. [15] have determined that dicofol acts as a mitochondrial electron transport inhibitor, studies suggest that some organochlorine pesticides and the hydroxylated breakdown products of carbaryl are inhibitory towards mitochondrial electron transport systems in vitro. Further investigations should be conducted to determine if the inhibition of mitochondrial electron transport systems is of toxicological importance in the intact organism. Consequently, dicofol ought to be compared with products that have the same mode of action, such as chlorfenapyr, hydramethylnon and pyridaben.

Chlorfenapyr synthesis was developed by $\mathrm{Xu}$ [16] starting from $\alpha$-p-chlorophenyl) glycine, Scheme 6. Glycine reacts with trifluoroacetic anhydride, and latterly with 2-chloroacrilonitrile, giving an intermediate that is 2-(p-chlorophenyl)-5-(trifluoromethyl)pyrrol-3-carbonitri le. This intermediate reacts through a bromination reaction at pyrrol ring in the presence of a weak base, and the resulting bromide performs an ethoxymethylation with methyl dibromide and sodium ethoxide, total yield is $65 \%$. Chlorfenapyr purity is $95 \%$, and the bromination process has been improved significantly.

Hydramethylnon synthesis was achieved through the coupling in alcoholic media refluxing the compound 1,5-bis[ $p$-(trifluoromethoxy)phenyl]-1,4-pentadien-3-one afforded the desired product in 50\% yield [17], Scheme 7. 


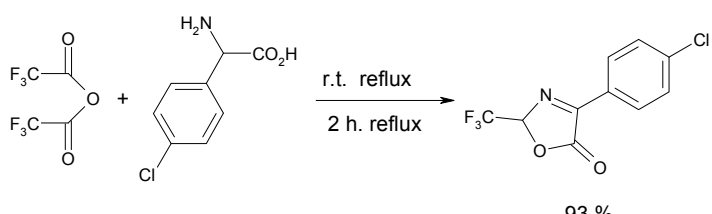

$93 \%$

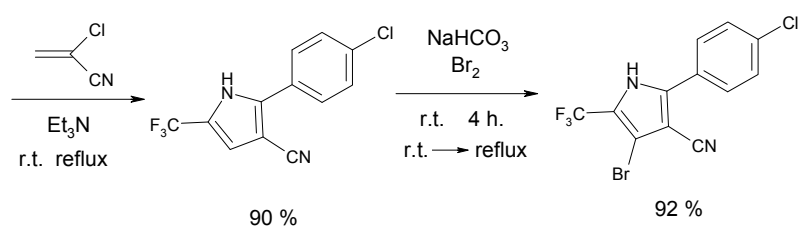

i) $\mathrm{NaH}, \mathrm{THF}, 30$ min. r.t.

ii) $\mathrm{CH}_{2} \mathrm{Br}_{2}, \mathrm{NaOEt}, 2$ h. reflux. 12 - 16 h. r.t.

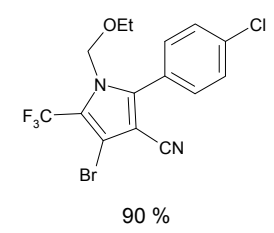

Scheme 6. Synthesis of chlorfenapyr.

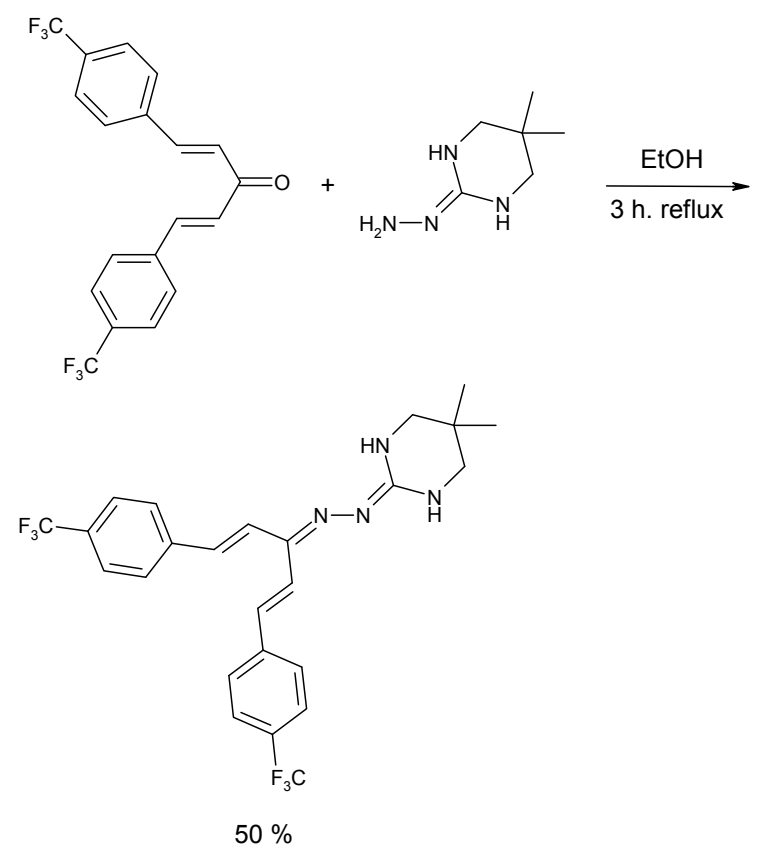

Scheme 7. Synthesis of hydramethylnon.

Pyridaben synthesis was developed by $\mathrm{Xu}$ [18] starting from 2-tert-butyl-4,4-dichloropyridazin-3(2H)-one, and 4-tert-(butylphenyl)methanothiol, in sodium methoxide media, stirring for one hour at controlled temperature, obtaining the final product in $96 \%$ yield, Scheme 8 .

\subsubsection{Pesticide Alternatives to Dicofol of Common Use} Other pesticides analyzed due to its major use in different crops are oxythioquinox, fenbutatin-oxide and formetanate hydrochloride [19]. These alternatives are more poi- sonous than dicofol to beneficial insects, but many trials suggest that the efficacy is superior even though the production lost is about three percent. Oxythioquinox is a sulphur containing chemical, this quinoxaline-2,3-dithiocarbonate is obtained reacting a quinoxaline-2,3-dithiol substituted with an alkyl group with a carbonylating agent selected from triphosgene, and diphosgene. It is preferable that the quantity of the carbonylating agent is $0.34-5$ molar times, for triphosgen, or 0.5-5 molar times, for diphosgene. The above reaction is better conducted under basic conditions to scavenge hydrochloric acid produced as by-product. The reaction temperature has to be maintained from -78 to $50^{\circ} \mathrm{C}$ [20], Scheme 9 .

An alternative synthesis to obtain this product starts from 2,6-dimercapto-6-methylquinoxaline that reacts with an hydroxide or the alike of an alkali metal in water or an alcohol solvent, and an organic solvent such as aromatic hydrocarbons, for example, toluene or xylene is added to the reaction mixture. The reaction mixture with the organic solvent is subjected to an azeotropic dehydration and a solvent replacement to form an alkali salt, and the alkali salt is reacted with the intermediated, where $\mathrm{R}$ is a methyl group preferably in an amount of 1.0-4.0 molar times in the presence of a phase transfer catalyst (e.g. a quaternary ammonium salt or a pyridinium salt) in an amount of $1-5 \% \mathrm{~mol} \%$ at $0-150{ }^{\circ} \mathrm{C}$ for $0.5-10 \mathrm{~h}$. to provide the objective compound S,S-(6-methylquinoxaline2,3-diyl)dithiocarbonate [21], Scheme 10.

Fenbutatin-oxide is an organotin compound, the synthesis of this compound is achieved starting from neophyl chloride, it occurs through a magnesium intermediate that reacts with tin tetrachloride, hydrolysis adding
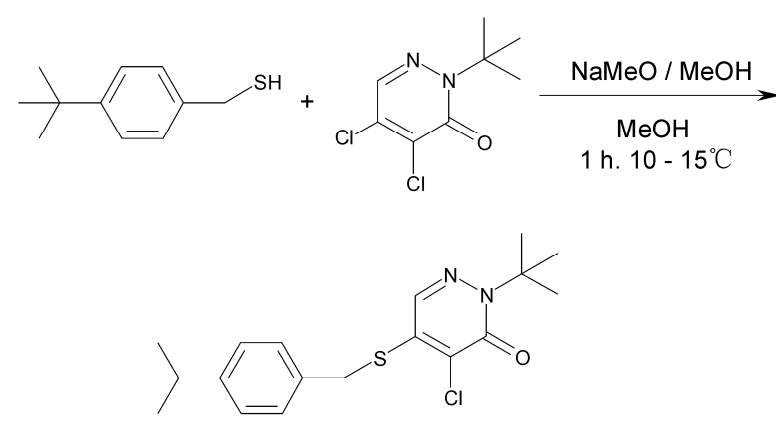

$96 \%$

Scheme 8. Synthesis of pyridaben.<smiles>Cc1ccc2[nH]c(=S)c(=S)[nH]c2c1</smiles>

Scheme 9. Synthesis of oxythioquinox. 
sodium hydroxide provides the final product [22], Scheme 11.

Formetanate hydrochloride is a bifuntional pesticide, so the two reactive groups of this molecule are formamidine and carbamate, and this remarks the water solubility, and also the toxicity and potential mobility in aqueous environments. The formetanate is obtained from meta-aminophenol and dimethylformamide in phosphorous oxychloride, after purification of the intermediate and reaction with methyl isocianate and acid treatment produce the formetanate [23], Scheme 12. The final step in the synthesis may be accomplished by treating the formetanate with the appropriate acid chloride or anhydride in an inert solvent as diethyl ether [24].<smiles>Cc1ccc2[nH]c(=S)c(=S)[nH]c2c1</smiles>

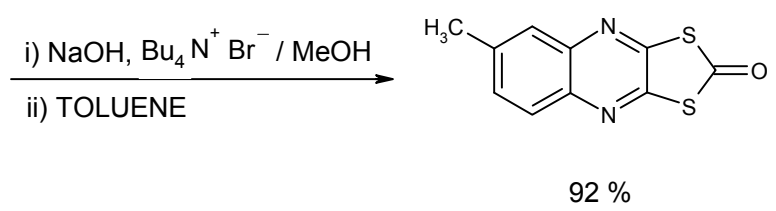

Scheme 10. Alternative synthesis of oxythioquinox.
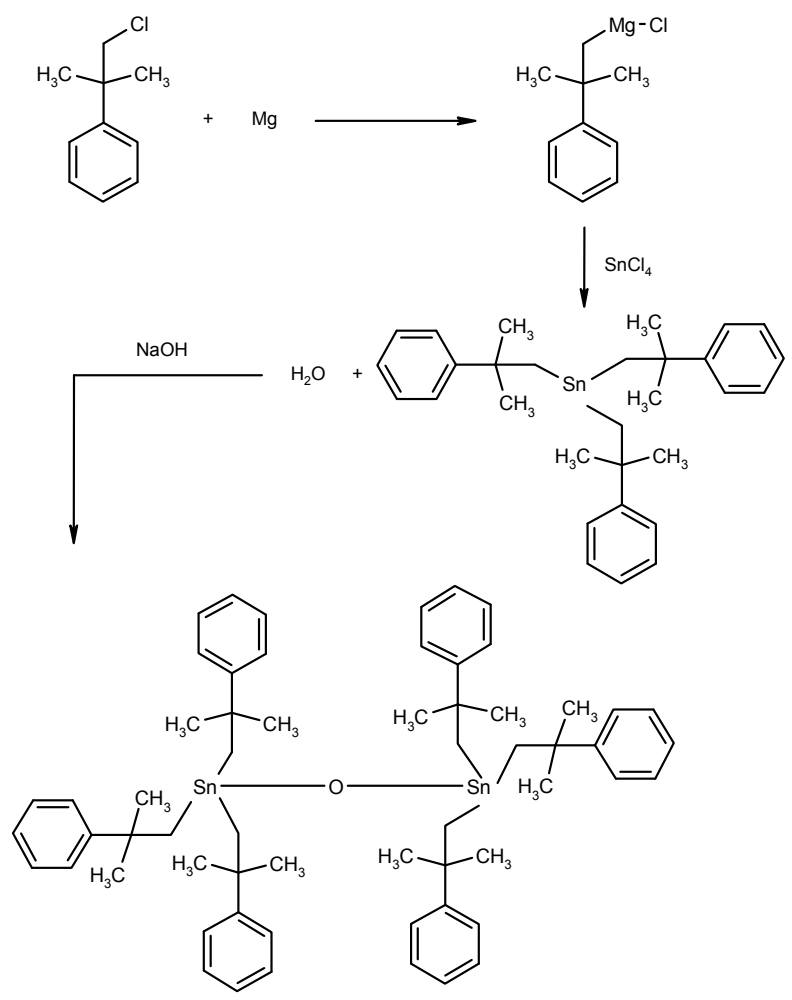

Scheme 11. Synthesis of fenbutatin-oxide.<smiles>CNC(=O)Oc1cccc(N=C=NC(C)C)c1</smiles>

Scheme 12. Synthesis of formetanate.

These anthropogenic compounds have some structural similarities, due to the relation structure-toxicity; most of them are organochlorines pesticides.

Dicofol is a chlorinated compound as well as chlorfenapyr and pyridaben, similarly dicofol shows a trichloromethyl group, and chlorfenapyr and hydramethylnon have a trifluoromethyl group, in most cases fluor enlarge the activity of a biologically active compound. Sulphur is contained in pyridaben and oxythioquinox, as historically use of pure sulphur to control insect pests.

Diazacompounds exhibit also activity as pyrimidine in hydramethylnon, pyridazine in pyridaben and a piperazine moiety in oxythioquinox. Another hit that increase the toxicity can be explained by the para-substitution, as in dicofol, hydramethylnon, pyridaben and oxythioquinox. Toxicity in fenbutatin-oxide can be explained by the metal element, since organo tin substances are known to disturb growth, reproduction, enzymatic systems and feeding patterns of aquatic organism.

Triethyltin is the most dangerous organo tin substance for humans. It has relatively short hydrogen bonds. When hydrogen bonds grow longer a tin substance will be less dangerous to human health. So that is why fenbutatinoxide increases volume with a phenyl group. The dimmer explains double amount of toxic substance. The molecule geometry is important, as DDT and dicofol have a Z group of sufficient steric size, e.g. trichloromethyl, to inhibit the free rotation of the planar phenyl rings so that they are constrained to positions of minimum steric grouping, termed a trihedral configuration. Other symmetrical molecules are hydramethylnon and oxythioquinox (except methyl substitution that can be here considered as a minor group, since this group does not interfere with the $\mathrm{C}_{2}$ operation).

Formetanate hydrochloride has two possible active moieties, is both arylformamidine and arylcarbamate groups, it appears to exert its toxicity to rats, houseflies, and mites as an anticholinesterase agent than a formamide [25], carbamates inhibit cholinesterase and prevent the termination 
of nerve impulse transmission. The formetanate salt must be prepared to improved aqueous solubility since the carbamates are systemic to roots via soil applications or through leaves from foliar applications [26].

\section{Environmental and Human Effects of Selected Chemicals Alternatives to Dicofol}

Dicofol is a miticidal pesticide and acaricide, its precursor DDT was a revolutionary pesticide in agriculture, since it eradicated malaria from North America and Europe [27]. There is evidence that DDT plays a role in the aetiology such as pancreatic cancer, neuropsychological dysfunction, and reproductive outcomes. Research into these and other conditions would benefit from the same rigorous approaches used in breast cancer research. Until further high quality evidence is available, it is still too early, even 60 years after the introduction of this once ubiquitous chemical, to pass judgement on the role of DDT in a number of common diseases. This im- plies dicofol could produce the same injuries to humans since the structure similarities.

The possible alternatives listed show acaricide function as a majority function, Table 2, mode of action is for chlorfenapyr oxidative phosphorylation inhibition, given that it provokes a disruption of production of adenosine triphosphate (ATP) [29], this induces the cellular death and ultimately organism mortality, fenbutatin-oxide also inhibits oxidative phosphorylation [39], but this compound is non-systemic - a systemic pesticide is when the chemical is transported from the place of application to other parts of a plant or animal - so the product must usually be ingested by the organism [40], this usually affects beneficial insects. Dicofol has been widely use to control vine mites, the suggestion of DDTr residues in dried fruit or wine products is potentially extremely damaging to viticultural industry. At this moment there are few chemical alternatives cheap and effective, as long as the only miticide presented here is oxythioquinox,

Table 2. Summary of environmental and human effects of alternatives to dicofol.

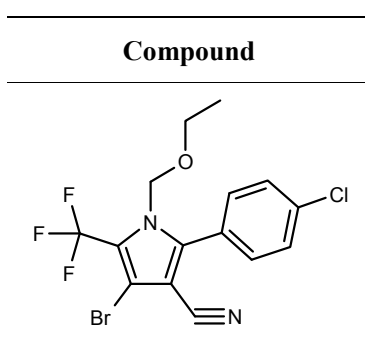

CHLORFENAPYR

Activity

Acaricide, Insecticide

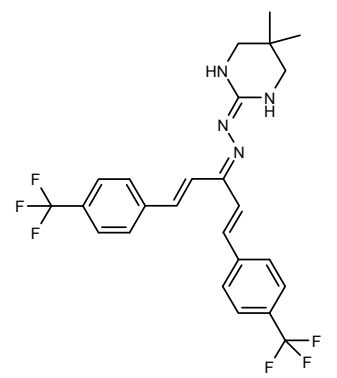

HYDRAMETHYLNON

Activity

Insecticide, broad-spectrum fase effective acaricide.

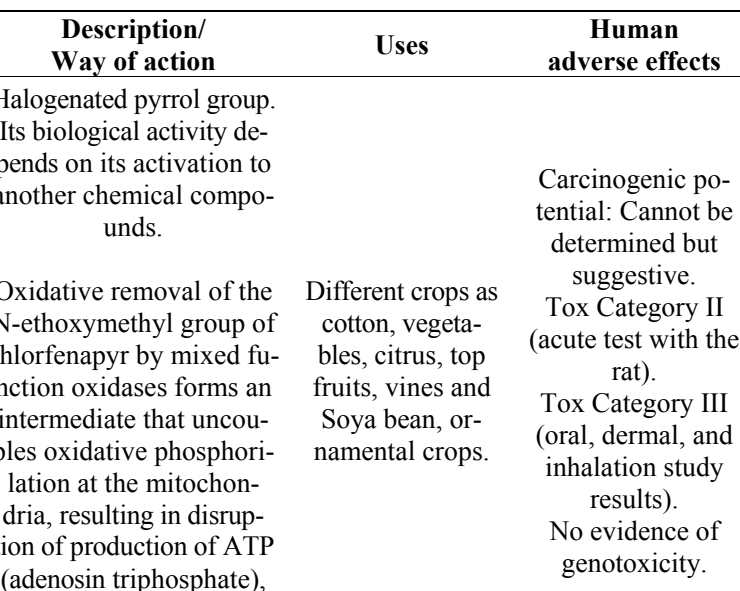

(adenosin triphosphate), cellular death and ultimately organism mortality.

Trifluroromethylamino hidrazones group, which act as a metabolic inhibitor.

Causes death by inhibiting the formation of ATP (adenosine triphosphate); ATP provides the energy neces- sary for completing most biological processes, without ATP insects just die.
Carcinogenic potential Group C: Possible Human Carcinogen (U.S EPA, 1996).

Tox Category III (acute test oral and dermal with the rat).

Tox Category IV (acute test inhalation with the rat). No genotoxic in microbial test systems or clastogenic in cultured mammalian cells. Not induce dominant lethality in male rat germinal cells.
Especially toxic for fishes. High bioconcentration potential, even though its bioaccumu-

[28, lation potential is low.
$31,32] \quad$ Moderated toxicity for mammals, birds, fishes an aquatic invertebrates, algae and beneficial organism. 
Table 3. Summary of environmental and human effects of alternatives to dicofol.

\begin{tabular}{|c|c|c|c|c|c|c|}
\hline Compound & $\begin{array}{c}\text { Description/ } \\
\text { Way of action }\end{array}$ & Uses & $\begin{array}{c}\text { Human } \\
\text { adverse effects }\end{array}$ & Ref. & Associate impact & Ref. \\
\hline $\begin{array}{c}\text { Activity } \\
\text { Non-systemic acaricide and } \\
\text { insecticide which is active } \\
\text { control of mites and whiteflies. }\end{array}$ & $\begin{array}{l}\text { Pyridazone group. } \\
\text { Acts as a mitochondrial } \\
\text { electronic transport in- } \\
\text { hibitor at complex I } \\
\text { mode of action. }\end{array}$ & $\begin{array}{l}\text { Control of mite } \\
\text { and white flies } \\
\text { on ornamental } \\
\text { plants, flowers } \\
\text { and foliage } \\
\text { (non-food) crops } \\
\text { in green houses, } \\
\text { and for the use to } \\
\text { control mites on } \\
\text { apples, pears and } \\
\text { almonds. } \\
\text { Grapes, apricots, } \\
\text { cherries, } \\
\text { nectarines, } \\
\text { peaches, } \\
\text { pistachio, plums, } \\
\text { prunes and the } \\
\text { tree nut group. }\end{array}$ & $\begin{array}{l}\text { Carcinogenic } \\
\text { potential: Group E: } \\
\text { Evidence of } \\
\text { Non-Carcinogenici } \\
\text { ty for humans } \\
\text { based on the lack } \\
\text { of evidence of } \\
\text { carcinogenicity in } \\
\text { male and female } \\
\text { rats as well as in } \\
\text { male and female } \\
\text { mice. } \\
\text { Toxicity to hu- } \\
\text { mans, including } \\
\text { carcinogenicity, } \\
\text { reproductive and } \\
\text { developmental } \\
\text { toxicity, neurotox- } \\
\text { icity, and acute } \\
\text { toxicity. Biocon- } \\
\text { centration and } \\
\text { bioaccumulation } \\
\text { factors are low. It } \\
\text { has been demon- } \\
\text { strated human } \\
\text { toxicity since it is } \\
\text { harmful for neuro- } \\
\text { blastoma cells }\end{array}$ & {$[28,34]$} & $\begin{array}{l}\text { Water quality stan- } \\
\text { dards and physical } \\
\text { properties affecting } \\
\text { water contamination } \\
\text { potential. Aquatic } \\
\text { toxicity, bioconcentra- } \\
\text { tion and environmental } \\
\text { fate of pyridaben are } \\
\text { similar to synthetic } \\
\text { pyrethroids used in } \\
\text { agriculture, the main } \\
\text { distinguishing feature } \\
\text { is that pyridaben is } \\
\text { more photo-labile than } \\
\text { most pyrethroid, pyri- } \\
\text { daben can be photo- } \\
\text { chemically degraded } \\
\text { (Rand et al., 2000) } \\
\text { Acute-to-chronic ratios } \\
\text { for pyridaben are low } \\
\text { for fish and inverte- } \\
\text { brates indicating a low } \\
\text { potential for residual } \\
\text { activity. }\end{array}$ & {$[35,36]$} \\
\hline $\begin{array}{c}\text { Activity } \\
\text { Insecticide, acaricide, } \\
\text { fungicide, ovicide. }\end{array}$ & $\begin{array}{l}\text { Thiocarbamate group. } \\
\text { The binding of oxythio- } \\
\text { quinox to proteins prob- } \\
\text { able evolved a mecha- } \\
\text { nism by which the sulf- } \\
\text { hydryl group of proteins } \\
\text { initially attacked the } \\
\text { carbonyl carbon of the } \\
\text { acaricide, and the acari- } \\
\text { cidal action of oxythio- } \\
\text { quinox is due to the } \\
\text { disruption of the normal } \\
\text { function of significant } \\
\text { proteins by the parent } \\
\text { compound itself. }\end{array}$ & $\begin{array}{l}\text { Only to use on } \\
\text { non-food crops } \\
\text { (landscape or- } \\
\text { namentals) and } \\
\text { places (nurseries } \\
\text { and green- } \\
\text { houses). It is } \\
\text { reported to be } \\
\text { incompatible } \\
\text { with oils (caus- } \\
\text { ing phytotoxic- } \\
\text { ity). }\end{array}$ & $\begin{array}{c}\text { Carcinogenic } \\
\text { potential: Group } \\
\text { B2 (probable hu- } \\
\text { man carcinogen) } \\
\text { based on lung } \\
\text { tumours in males } \\
\text { mice. } \\
\text { Toxicity Category } \\
\text { III or IV. Category } \\
\text { II: Causes ire- } \\
\text { versible eye dam- } \\
\text { age. Some by- } \\
\text { standers may ex- } \\
\text { perience a skin } \\
\text { reaction similar to } \\
\text { sun burn, particu- } \\
\text { larly if wind is } \\
\text { present during } \\
\text { applications. }\end{array}$ & $\begin{array}{c}{[28,} \\
37,38]\end{array}$ & $\begin{array}{l}\text { Moderately toxic to } \\
\text { birds and adversely } \\
\text { affected egg produc- } \\
\text { tion, embryo survival } \\
\text { (and perhaps fertility), } \\
\text { hatch ability, offspring } \\
\text { body weight and sur- } \\
\text { vival of offspring in } \\
\text { avian reproduction } \\
\text { studies. } \\
\text { Highly toxic to fish } \\
\text { and other aquatic or- } \\
\text { ganisms. }\end{array}$ & {$[38]$} \\
\hline
\end{tabular}

Table 3, and it is no recommended for food crops, since it is a probable human carcinogen.

Formetanate hydrochloride has been applied predominantly to nectarines crops, and the way of action is similar to fenbutatin-oxide [41], Table 4, the toxicology is determined by its high solubility in water, more than $800.00 \mathrm{mg} / \mathrm{l}$, since it is widespread in contaminated water, it supposes a great danger for aquatic organism, even though there is no complete data in the risk assessment about injuries to freshwater fish or invertebrates $[42,43]$. Its acetyl cholinesterase action can even affect to human, since it has acute toxicity via oral route. Formetanate hydrochloride is considered a Group E, carcinogenic potential since there is evidence of no-carcinogenecity for humans [28]. Hydramethylnon is used to control ants and cockroaches in domestic and commercial establishments, but pyridaben is more used to control mites outdoor, in different crops of flowers and ornamental plants, and in grapes, apricots, etc. [31,32]. Pyridaben can be photochemically degraded, acute and chronic ratios for fish and invertebrates are low, as well as its bioconcentration and bioaccumulation potential, in front of dicofol. Hydramethylnon and pyridaben provoke death by inhibiting the formation of ATP $[32,34]$, the difference is that 
Table 4. Summary of environmental and human effects of alternatives to dicofol.

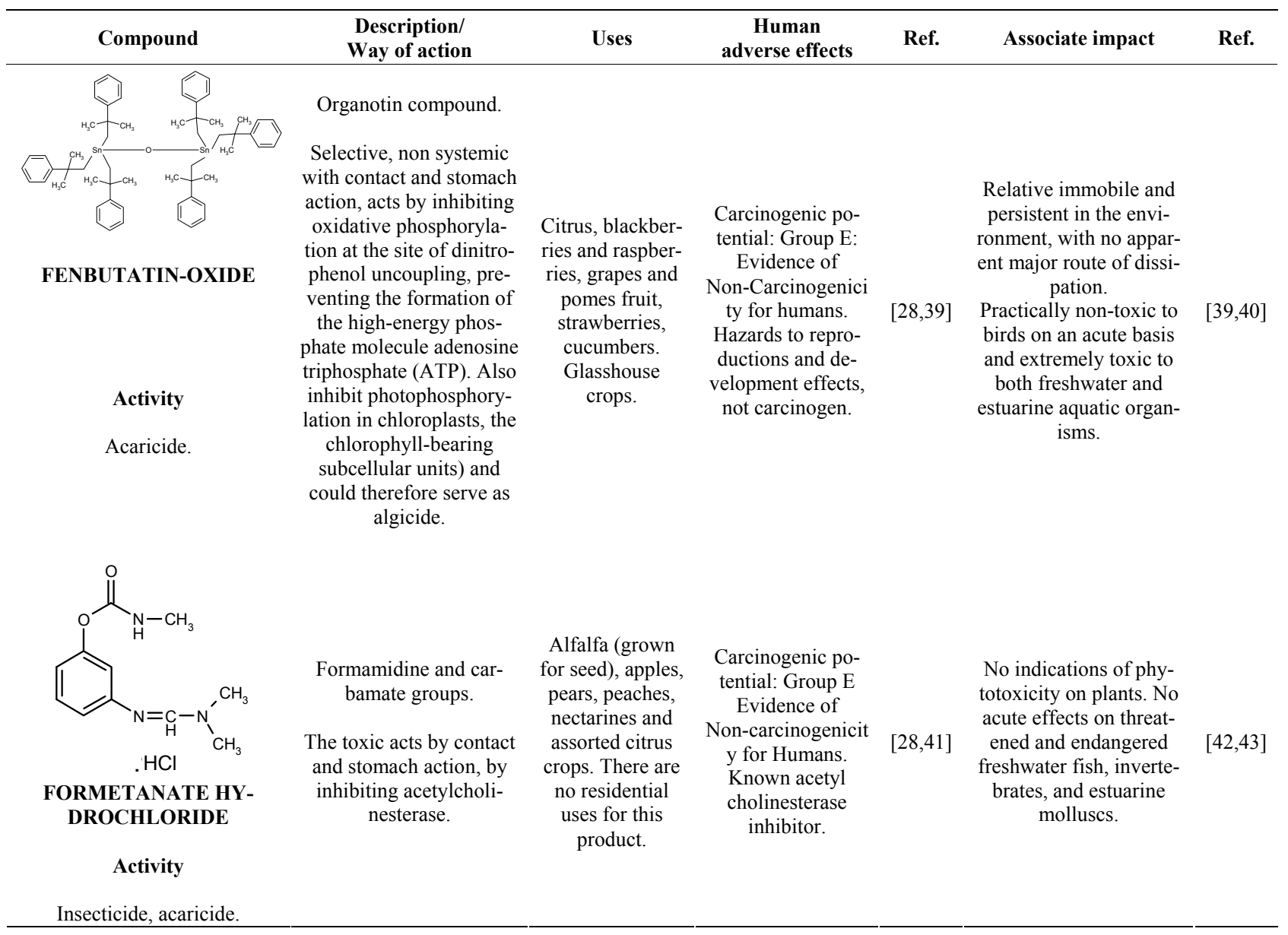

hydramethylnon inhibits mitochondrial complex III electron transport (site II) and pyridaben inhibits mitochondrial complex I electron transport. It is known that this causes gradual degeneration of the dopamine neurons and reproduce many of the features of Parkinsonism. Pyridaben is a Group E, evidence of no-carcinogenecity for humans, and hydramethylnon and dicofol are classified as Group C, carcinogenic potential of possible human carcinogen [28].

\section{Conclusions}

On the basis of available scientific data, different alternatives for substitution of dicofol examinated here are directly related with the chemical structure, and the toxicity of these compounds is at least as potent as dicofol, affecting environmental and human beings.

Properties that identify substances as substances of high concern (CMR and PBT profile) are discussed in order to assess the possible substitution alternatives to dicofol. The understanding of the structure of compounds and their correlation to target organism is a very impor- tant parameter to develop better designed pesticidal compounds with tailored toxicological properties on different pests. Mode of action of fuoroalkenyl derivatives is demonstrated to act in "specific manner" depending on the crop and the pest. Chemical inhibitor agents of mitochondrial electron transport are as dangerous as dicofol to environment and/or humans. The third group is better for humans but in most cases is worst for the environment, aquatic life specific. Common sense leads to make insecticide selection decisions which can ensure the most effective, least expensive and least environmentally disruptive methods, considering the mode of action, resistance, phytotoxicity, and the possibility of introduce other biological species to protect crops against pests.

\section{REFERENCES}

[1] M. H. C. Rasenberg and E. J. van de Plassche, "Risk Profile and Summary Report for Dicofol," Dossier Prepared for the UNECE Convention on Long-Range Transboundary Air Pollution's Expert Group on POPs, Nijmegen, The Netherlands, April 2003. 
[2] OSPAR, "OSPAR Background Document on Dicofol (Draft Presented by Finland)," OSPAR 02/7/8-E, Meeting of the OSPAR Commission, Amsterdam, The Netherlands, 24-28 June 2002.

[3] Regulation (EC) No 850/2004 of the European Parliament and of the Council of 29 April 2004 on Persistent Organic Pollutants and Amending Directive 79/117/EEC.

[4] D. van Vijk, R. Chènier, T. Henry, M. D. Hernando and C. Schulte, "Integrated Approach to PBT and POP Prioritization and Risk Assessment," Integrated Environmental Assessment and Management, Vol. 5, No. 4, 2009, pp. 697-711.

[5] E. J. van de Plassche and M. H. C. Rasenberg, "Dicofol Dossier Prepared for the Third Meeting on the UN-ECE Ad-hoc Expert Group on POPs," Nijmegen, The Netherlands, April 2002.

[6] B. A. Narloch, M. P. Lawton, D. E. Moody, B. D. Hammock and L. R. Shull, "The Effect of Dicofol on Induction of Hepatic Microsomal Metabolism in Rats," Pesticide Biochemistry and Physiology, Vol. 28, No. 3, 1987, pp. 362-370.

[7] S. E. Schwarzbach, "The Role of Dicofol Metabolites in the Eggshell Thinning Response of Ring Neck Doves," Archives of Environmental Contamination and Toxicology, Vol. 20, No. 2, 1991, pp. 200-205.

[8] E. J. van de Plassche, A. M. G. R. Schwegler, M. Rasenberg and G. Schouten, "DDT in Dicofol," In: Further Assessment of Persistent Organic Pollutants (Pops). Compendium of Substance-Related Information, Convention on Long-Range Transboundary Air Pollution, UNECE 2002.

[9] H. S. Mosher, M. R. Cannon, E. A. Conroy, R. E. Van Strien and D. P. Spalding, "Preparation of Technical DDT. Industrial and Engineering Chemistry," Vol. 38, 1946, pp. 916-923. See reference 1) A. Baeyer, Chemische Berichte, Vol. 5, 1872, pp. 1094-1100.

[10] J. H. Simons, J. C. Bacon, C. W. Bradley, J. T. Cassaday, E. I. Hoegberg and P. Tarrant, "The Preparation of DDT Using Hydrogen Fluoride as the Condensing Agent," Journal of the American Chemical Society, Vol. 68, No. 8, 1946, pp. 1613-1615.

[11] A. Kalusyner, "Cyclic Analogs of DDT-Like Compounds," Journal of Organic Chemistry, Vol. 25, No. 3, 1960, pp. 473-474.

[12] C. C. Tang, Y. C. Li, B. Chen, H. Z. Yang and G. Y. Jin, "In Pesticide Chemistry," in Chinese, Nankai University Publishing House, Tianjian, 1998, p. 230.

[13] P. Kaushik and G. Kaushik, "An Assessment of Structure and Toxicity Correlation in Organochlorine Pesticides," Journal of Hazardous Materials, Vol. 143, No. 1-2, 2007, pp. 102-111.

[14] Y. Hu, E. W. Reed and Y. Song, "Fluoroalkenyl Derivatives as Insecticides and Nematicides and their Preparation and Use in Combination with Other Biological Active Agents," Patent WO2007089455, 2007.

[15] R. S. Pardini, J. C. Heidker, T. A. Baker and B. Payne,
"Toxicology of Various Pesticides and their Decomposition Products on Mitochondrial Electron Transport," Archives of Environmental Contamination and Toxicology, Vol. 9, No. 1, 1980, pp. 87-97.

[16] S. Xu, M. Jiang, Y. Yu, X. Wang, Q. Wan and Z. Xu, "Synthesis of Insecticide Chlorfenapyr," Journal of Nanjing Agricultural University, Vol. 27, No. 2, 2004, pp. 105-108.

[17] J. B. Lovell, American Cyanamid Co. USA, Patent US77-793117, 1978.

[18] L.-S. Xu, G.-P. Yu, Z.-J. Xu, G.-S. Zhang and Z.-W. Zhai, "Synthesis and Crystal Structure of 2-tert-Butyl-5-(4-tertbutylbenzylthio)-4-chloropyridazin-3(2H)-one," Chemical Research in Chinese Universities, Vol. 22, No. 6, 2006, pp. 763-764.

[19] L. Gianessi and N. Reigner, "Pesticide Use in U.S. Crop Production: 2002," CropLife Foundation, Washington D.C., May 2006.

[20] F. Yoshiro and M. Masafumi, "Production of Quinoxaline Dithicarbonate or its Derivative," Patent JP10316682, 1998.

[21] K. Iku, S. Hiroyoshi and M. Yasuo, "Production of S,S(6-Methylquinoxaline-2,3-diyl)dithiocarbonate," Patent JP $11080133,1999$.

[22] T. A. Unger, "Pesticide Synthesis Handbook," Noyes Publications, Park Ridge, NJ, 1996, p. 400.

[23] T. A. Unger, "Pesticide Synthesis Handbook," Noyes Publications, Park Ridge, NJ, 1996, p. 83.

[24] D. Pont, "Naphtoquinones and their Use as Pesticides," Patent GB1518750, 1978.

[25] R. M. Hollingworth, "Chemistry, Biological Activity, and Uses of Formamidine Pesticides," Environmental Health Perspectives, Vol. 14, 1976, pp. 57-69.

[26] "Integrated Pest Management in the Greenhouse Growers: Information on Insecticides for Greenhouse Growers," OSU Extension Factsheet No. 6712, 2007.

[27] J. Beard, "DDT and Human Health," Science of the Total Environment, Vol. 355, No. 1-3, 2006, pp. 78-89.

[28] "List of Chemicals Evaluated for Carcinogenic Potential," Proposed EPA Weight of the Evidence Categories, U.S. EPA, 1996.

[29] "Pesticide Fact Sheet Chlorfenapyr EPA-730-F-00-001," U.S. EPA, 2001.

[30] S. Zhang, "Chlorfenapyr Water-Dispersible Granule and its Preparation," Patent CN101194609, 2007.

[31] "Re-evaluation of Hydramethylnon NTIS/00400217," U.S. EPA, 2003.

[32] "Reregistration Eligibility Decision (RED) EPA-738-R98-023," U.S. EPA, 1998.

[33] “Federal Register 68, 48302-48312,” U.S. EPA, 2003.

[34] PAN Pesticide Database, Pesticide Action Network, North America, 2000-2009. http://www.pesticideinfo.org/

[35] G. M. Rand and J. R. Clark, "Hazard Risk Assessment of Pyridaben: I. Aquatic Toxicity and Environmental Chem- 
istry," Ecotoxicology, Vol. 9, No. 3, 2000, pp. 157-168.

[36] G. M. Rand and J. R. Clark, "Hazard Risk Assessment of Pyridaben: II. Outdoor Aquatic Toxicity Studies and the Water-Effect Ratio," Ecotoxicology, Vol. 9, No. 3, 2000, pp. 169-177.

[37] C. O. Knowles, "Chemistry and Toxicology of Quinoxaline, Organotin, Organofluorine, and Formamidine Acaricides," Environmental Health Perspectives, Vol. 14, 1976, pp. 93-102.

[38] "R.E.D. FACTS Prevention, Pesticides and Toxic Substances (7508C) EPA-738-F99-018," U.S. EPA, 1999.

[39] "Reregistration Eligibility Decision (RED) EPA-738-R-
94-024," U.S. EPA, 1994.

[40] Report from FOOTPRINT BDPP, ENT 27738, 2009. http://sitem.herts.ac.uk/aeru/footprint/es/index.htm

[41] Report from FOOTPRINT BDPP, SN 36056, 2009. http://sitem.herts.ac.uk/aeru/footprint/es/index.htm

[42] "Reregistration Eligibility Decision (RED) EPA-738-R06-015," U.S. EPA, 2006.

[43] A. R. Fernández-Alba, M. D. Hernando Guil, G. Díaz López and Y. Chisti, "Comparative Evaluation of the Effects of Pesticides in Acute Toxicity Luminescence Bioassays," Analytica Chimica Acta, Vol. 451, No. 2, 2002, pp. 195-202. 